\title{
TOWARDS A SUSTAINABLE INNOVATION FRAMEWORK TO ASSESS NEW INDO-SWISS COLLABORATION SCENARIOS
}

\author{
*Myrna Flores, **Mathew Cherian, ***Claudio Boër \\ *Swiss MTO Network - Swiss Federal Institute of Technology, Lausanne (EPFL) ${ }^{1}$ \\ myrflores@hotmail.com \\ **Indian Institute of Technology, Madras, Department of Management Studies \\ mathewch@lycos.ch \\ ***University of Applied Sciences of Southern Switzerland (SUPSI) \\ Department of Technology and Innovation, Institute CIM for Sustainable Innovation (ICIMSI) \\ claudio.boer@supsi.ch,SWITZERLAND
}

\begin{abstract}
The world is "becoming flat" (Friedman, 2005), this means that innovations are emerging thanks to the deployment of new open collaborative frameworks and Information and Communication Technologies that enable the development of new products and services. Additionally, there are two key emerging trends changing the business arena: 1) the fast development of economies, such as China and India that besides low cost opportunities also represent new attractive markets counting together with more than 2 billion people and which at the same time are investing to improve their innovation capabilities and 2) the acknowledgement of the latent worldwide need to care not only about economic returns, but also about the social welfare of human beings, in whichever market they live, and the impact that any type of organisation has on the environment to diminish worries such as global warming, energy consumption and waste. Therefore, the goal of this paper is twofold: 1) propose a sustainable innovation framework that integrates four key enablers and 2) explain how this framework was applied in the SWISSMAIN project to assess and compare seven identified scenarios to enable Swiss and Indian firms to collaborate towards new business opportunities considering economic, social and environmental impacts..
\end{abstract}

\section{INTRODUCTION}

In the last years there has been a growing interest on the terms "Innovation" and "Collaboration". Many authors have given several definitions; but we could say that one word for Innovation is "change". Innovation means doing things in a different way, changing the rules of the game to improve the current status quo. The outputs are new products, processes and/or services that have business returns to give firms competitive advantage. What about "Collaboration"? In very simple terms it means doing things together, integrating partners inside and outside the organisational boundaries towards a shared strategy.

Even though these two terms seem very fashionable and simple to understand in terms of meaning, for most organisations is difficult to implement them successfully

\footnotetext{
${ }^{1}$ Dr. Myrna Flores was a visiting researcher as part of the Swiss MTO Network in EPFL during 2007
} 
in and individual way and even more challenging to apply in real business real scenarios when different organisations collaborate to achieve a common goal.

As a consequence, different approaches have been proposed to motivate and support different organisations to target innovations in a collaborative way. In Europe, the Breeding Environment approach emerged due to the success of several FP5 and FP6 EU funded research projects, which follow EU policies that stress the need of companies to collaborate in networks to share risks; competences and knowledge increase their success. One key project for the diffusion of this approach was the FP6 ECOLEAD Project. A Breeding environment represents an association or pool of organizations and their related supporting institutions that have both the potential and the will to cooperate with each other through the establishment of a "base" long-term cooperation agreement and interoperable infrastructure (Camarinha-Matos and Afsarmanesh, 2004).

Another approach to enhance innovation and collaboration is the one followed by the Living Labs Europe Project, which defines a the Living Lab as a "city area which operates a full-scale urban laboratory and proving ground for inventing, prototyping and marketing new mobile technology applications. A Living Lab includes interactive testing, but is managed as an innovation environment well beyond the test bed functions. As a city-based innovation resource the Living Lab can take advantage of the pools of creative talent, the affluence of socio-cultural diversity, and the unpredictability of inventiveness and imagination in the urban setting". Even though initially the Living Labs Europe Project targeted mobile applications, the concept is now applied to different sectors towards the creation of city based innovation hubs.

Additionally, the open innovation model (Chesbrough, 2006) proposes a broader collaborative approach, not linked to specific regions or partners, where as the author indicates "different partners should take much greater use of external ideas opening their business models". The open innovation approach also considers innovation intermediaries as those external entities that provide support to the innovation process.

Even if these models have made a great progress to enable firms understand and identify the potential new opportunities for innovation carried out in a collaborative way, there are still several uncovered angles. One key issue rarely integrated so far in most collaboration or networking approaches is "sustainability". This term is most of the times confused with the temporal space, in other words, it is being understood as making the innovation "durable" and "successful" in a long period of time. Nevertheless, the concept to be targeted in this paper goes beyond. Sustainability refers to networks of partners working in a collaborative environment, a living lab or an open innovation model which during the innovation process will consider the integration of the economic, social and environmental aspects of Sustainable Development.

The United Nations World Commission on Environment and Development reached a global consensus on the meaning of Sustainable Development: "development which meets the needs of the present without endangering the ability of future generations to meet their own needs".

The term refers to achieving economic and social development in ways that do not exhaust natural resources. At this point, the following research questions could be drawn: 
1) How do networks of partners be mobilised to collaborate for innovation outputs integrating the economic, social and environmental aspects of sustainable development achieving "sustainable innovations"?

2) Is there any framework that enables and guides single organisations and networks to concentrate in key aspects towards innovation and sustainable development?

3) How can partners in developing countries, which usually have another level of conscience about the social and economical aspects, integrate sustainable development, especially when collaborating with western partners?

\section{TOWARDS A SUSTAINABLE INNOVATION FRAMEWORK}

Sustainable innovation is a process where sustainability considerations (environmental, social and financial) are integrated into company systems from idea generation through to research and development (R\&D) and commercialisation. This applies to products, services and technologies, as well as new business and organisation models (Charter M. and Clark T., 2007). Even if the definition seems very simple and clear, still companies and networks struggle to understand how to integrate these concepts in their daily operations.

As a result, organisations which are part of collaborative networks could apply a framework to support a successful integration of the Sustainable Development principles and the development of highly innovative products and services for the global markets. In this regards, an integrated framework has been proposed to integrating four key enablers:

1. Mass customization (MC), relates to the ability to provide customized products or services through flexible processes in high volumes and at reasonably low costs (Da Silveira G., et. al., 2001). One key dimension is to provide sufficient product variety to meet diverse customer requirements, business needs and technical advancements while maintaining economies of scale and scope within manufacturing processes (Huang G., et. al., 2005). The current challenge in regards to a collaborative network is to target mass customisation following the sustainable development guidelines starting from the requirements gathering and design phase, integrating the different partners' competencies.

2. Sustainable Development (SD), targets the business holistic view of economic success taking care of wider environmental and social implications. Some authors argue that even if existing sustainable development policies, plans and programs within firms provide an important foundation on which to build efforts, they don't provide guidance to integrate the Sustainable Development concept in the day to day operations. Rocha, et. al (2007) have proposed a Sustainable Development Management System that integrates seven key elements: stakeholders, resources, leadership, processes, values, objectives and results. Additionally, other authors have stated the relevance of defining and implementing social and environmental performance indicators to follow up the impact in projects and technology life cycles (Brent C., et. al., 2007). Proper training to employees from the different partners of the network and incentives to change their mindsets may be required to achieve the expected results when collaborating. 
3. Value Network (VN), considers the need to right partner selection and network creation addressing also the environmental and social elements for sustainable innovation. Key activities under this enabler should focus on expanding the traditional focus on the forward flow of materials, components and products to explicitly address disposal, recycling, reconditioning and remanufacturing of used products (Kocabasoglu C., et. al., 2007). Additionally, different practices of knowledge management should also be addressed enabling different knowledge resources of sustainable development documents and know-how to be accessible by intra and inter-organisational partners to promote practices developed across organizational, professional, and multicultural boundaries to obtain multiplying effects (Wetherill M., et. al, 2007). This is particularly important for disseminating best practices to the network partners located in emerging markets, which usually don't assign sufficient resources to learn and implement Sustainable Development goals in real practice.

4. Product and Service Life Cycle thinking demonstrates an important paradigm shift because it inherently analyses impacts of products and services from cradle to grave, i.e. from resource extraction to final waste disposal addressing also environmental and social challenges. Companies can no longer afford being concerned only with product quality and production efficiency. Practical realizations of life cycle thinking in business strategies are numerous and include life cycle analysis (LCA), which lays ground for design for environment, eco-labelling, and environmental product declarations and environmental management systems (Mont O. and Bleischwitz R., 2007).

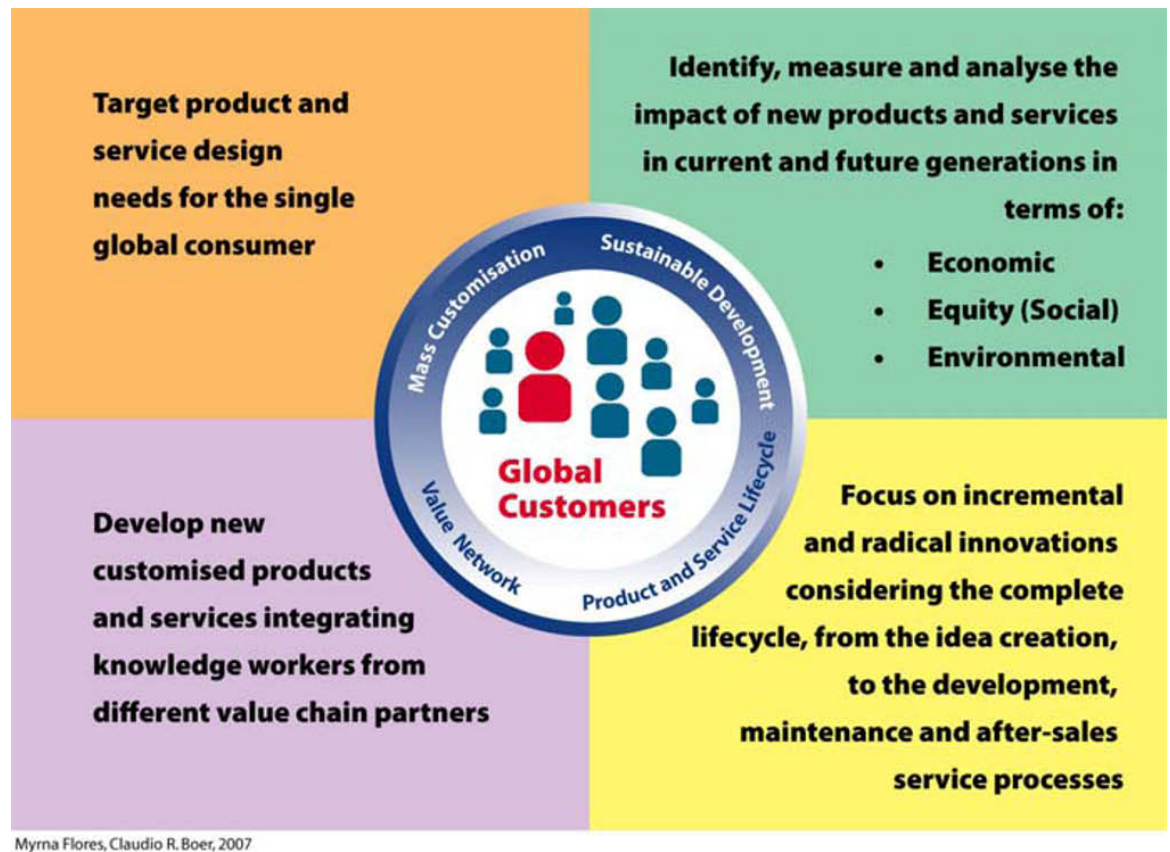

Figure 1. Integrated Framework for Sustainable Innovation (Source: Flores \& Boër, 2007) 
The following sections will provide and insight of how the proposed Framework for Sustainable Innovation has been applied in a research project to support Swiss SME's to analyse potential collaboration scenarios in India.

\section{THE SWISSMAIN INDIAN PILOT AND THE RESEARCH APPROACH}

The SWISSMAIN project is a research project funded by the Swiss Innovation Promotion Agency - CTI International. One key research interest of the industrial partners was to identify new possible business models or scenarios that could enable them to identify business and collaboration opportunities in India considering not only economic but also social and environmental issues.

As a result, the SWISSMAIN Indian pilot was launched with the objective to support Swiss and Indian companies in the machine building sector to identify collaboration opportunities considering sustainable innovation concepts (economic, social and environmental). One deliverable of this Indian Pilot was the development of scenarios to facilitate Swiss firms to identify different potential ways to do business in India to integrate and evolve into new collaborative environments, where not only Switzerland obtains sustainable benefits but also the Indian counterparts.

According to Schoemaker (1995), scenario planning enables managers to identify a big range of possibilities to capture different opportunities in rich detail; Scenario Planning is a disciplined method to imagine different futures that can be applied to greater range of futures simplifying the avalanche of data into a limited number of possible states. Even though the proposed SWISSMAIN scenarios were defined targeting new collaborative environments for Indo-Swiss collaborations, they could also be applied within other contexts.

The current state is the "AS-IS" scenario and applying the Scenario Planning research methodology seven different scenarios were identified and analysed after carrying out fifteen face to face interviews to companies both in India and Switzerland during the SWISSMAIN Indian pilot.

To identify, develop, compare and analyse the possible business scenarios among Swiss and Indian entrepreneurs, a questionnaire with both open and multiply choice questions was designed to carry out face to face interviews. This SWISSMAIN survey had as an objective to understand the current business arena from Swiss and Indian entrepreneurs considering their initial (past), current and future collaboration perspectives and integrating a Sustainable Development Framework (Flores, et al 2008). More specifically, the first part of the questionnaire focused on gathering data about: 1) the different reasons of Swiss companies doing business in India or vice versa, 2) the impact, 3) the main challenges and 4) the Critical Success Factors (CSF's). The second part had the objective to obtain information about the experiences of the Swiss companies doing business in India applying the three axes of sustainable development: economic, social and environmental.

Table 1 presents the AS-IS (status quo) and the seven scenarios identified in the SWISSMAIN Indian pilot applying the Scenario Planning research method (Schoemaker, 1995). Figure 2 represents the AS-IS scenario. 


\begin{tabular}{|c|c|}
\hline $\begin{array}{l}\text { AS IS } \\
\text { (status } \\
\text { quo) }\end{array}$ & $\begin{array}{l}\text { Swiss companies are mainly sourcing components from European suppliers but exporting } \\
\text { globally. There is currently no collaboration for product development with Indian partners. } \\
\text { Furthermore, in regards to product innovation and market introduction in India the presence } \\
\text { of Swiss firms is still very low in contrast to German and Japanese competitors. }\end{array}$ \\
\hline 1 & $\begin{array}{l}\text { EXPAND SOURCING AND SELLING TOWARDS PRODUCT CUSTOMISATION } \\
\text { The very first scenario, targets an expansion of current sourcing and selling activities in } \\
\text { India and also to increase customisation for emerging markets, considering: } \\
\text { - The Swiss company's production/assembly remains in Switzerland } \\
\text { - The Swiss firm assesses and selects new Indian suppliers, targeting a more collaborative } \\
\text { environment for product design and customisation for India } \\
\text { - Starts business collaborations, mainly selling and buying transaction } \\
\text { - Swiss finished product(s) are sold to the same markets and/or new markets (including } \\
\text { India) }\end{array}$ \\
\hline 2 & $\begin{array}{l}\text { CONCENTRATE SOURCING IN DEVELOPED/DEVELOPING INDUSTRIAL } \\
\text { CLUSTERS } \\
\text { The second identified scenario looks forward to motivate and enable Swiss firms to look for } \\
\text { business opportunities by collaborating with Indian partners located in established or } \\
\text { developing new clusters. In scenario } 2 \text { the following is considered: } \\
\text { - The Swiss company's production/assembly remains in Switzerland } \\
\text { - The Swiss company assesses and selects suppliers located in well established clusters } \\
\text { (industrial aggregations) in different locations in India taking advantage of scale } \\
\text { economies, networking activities and established infrastructure in the cluster (such a } \\
\text { training from local associations and Universities). } \\
\text { - New long term Indo-Swiss partnerships are built focusing on new product development or } \\
\text { re-design of products with local suppliers and customers }\end{array}$ \\
\hline 3 & $\begin{array}{l}\text { DEVELOP NEW CROSS BOARDER ALLIANCES (CBAs) } \\
\text { - The Swiss company looks for an existing Indian partner in the same or related market for } \\
\text { fast entry to Asian/Indian market } \\
\text { - Indian and Swiss partner form a new company with a common strategy and vision }\end{array}$ \\
\hline 4 & $\begin{array}{l}\text { FULL OWNERSHIP IN EMERGING MARKET } \\
\text { In this full ownership scenario, the Swiss opens a new production facility in India targeting } \\
\text { the local (Indian and/or emerging) market with existing products or customized ones } \\
\text { according to the local needs. Based on the different interviews carried out in Swiss } \\
\text { companies located in India, this is the most common current scenario of Swiss firms } \\
\text { investing in India as for many of them seems less risky due to the fact that business culture } \\
\text { is very different and unknown to Swiss counterparts, especially SME's }\end{array}$ \\
\hline 5 & $\begin{array}{l}\text { ACQUISITION IN EMERGING MARKET } \\
\text { In this scenario, the Swiss company searches, selects and performs a due diligence to } \\
\text { acquire a successful Indian-own established company in the same or similar industrial sector } \\
\text { to facilitate the company entry to that (Indian and/or Asian) market with existing products or } \\
\text { customized ones according to the local markets needs. }\end{array}$ \\
\hline 6 & $\begin{array}{l}\text { TECHNOLOGY TRANSFER TO FIRM IN EMERGING MARKET } \\
\text { This sixth scenario considers a Swiss company licensing technology to an Indian firm to } \\
\text { produce a finished product not existing in that particular emerging market. }\end{array}$ \\
\hline 7 & $\begin{array}{l}\text { NEW SERVICES PARTNERSHIPS } \\
\text { In this last identified scenario a Swiss company identifies an local firm(s) or organisation(s) } \\
\text { that can support delivering new value added services in that particular emerging market. } \\
\text { During the research project, both interviewed Indian and Swiss firms, mentioned that this } \\
\text { trend is growing. }\end{array}$ \\
\hline
\end{tabular}

Table 1. SWISSMAIN Collaboration Scenarios 


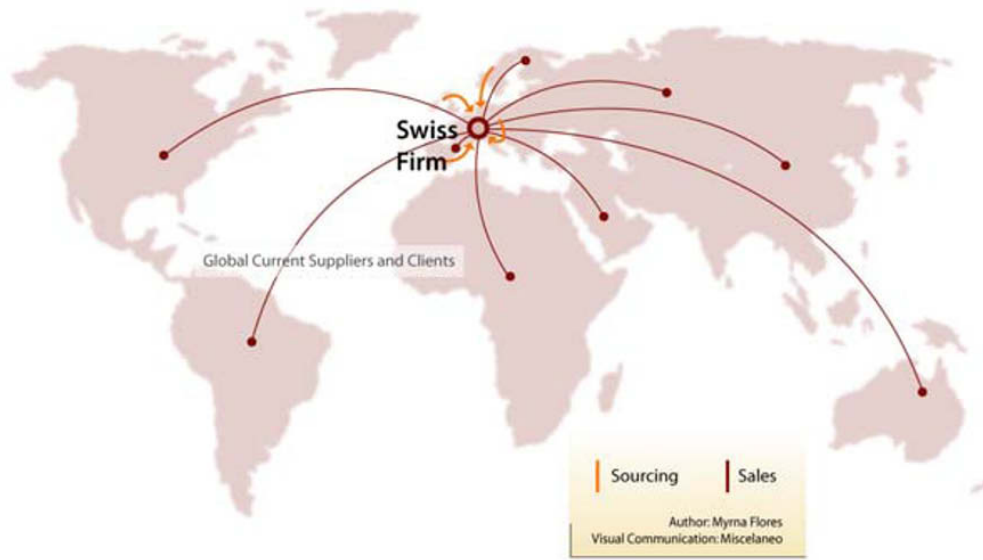

Figure 2. SWISSMAIN AS-IS Scenario

\section{APPL YING THE SUSTAINABLE INNOVATION FRAMEWORK TO ASSESS AND COMPARE THE SWISSMAIN SCENARIOS}

As observed from table 1, depending on the specific strategy, collaboration intensity, identified risks and business goals, different Indo-Swiss collaborative scenarios could emerge. Nevertheless, the proposed Sustainable Innovation framework (Figure 1) has been applied to assess and compare them. In other words, the proposed Sustainable Innovation Framework can be seen as a Benchmarking tool to compare the AS-IS with the seven identified scenarios. Table 2 provides an insight of the resulting comparison. For each scenario the level of impact has been identified for each of the enablers of the framework. Higher the intensity means that that enabler will be more strongly reinforced to achieve sustainable innovations. As observed, the AS IS scenario is the one that proposes less value or innovation creation to achieve sustainable innovations. This represents the starting point for companies to make decisions to select and further develop another TO BE scenario targeting both the potential collaboration with Indian counterparts integrating sustainable development principles.

In regards to product customisation, the seventh scenario "new services" can provide Indo-Swiss new collaborations higher impact, especially as the target will be to support the customisation of the local Indian needs with the local Indian skills in key processes such as design and after sales services.

In regards to sustainable development enabler, it seems obvious to think that the "full ownership" scenario of a Swiss company in India will have a very high impact as it will be "easier" to follow and implement current Environment Health and Safety (EHS) and green supply chain best practices followed in Switzerland in the new owned facility in India. Training to employees and suppliers could be carried out to transfer the EHS and green supply chain skills.

For the value network, working with "specialised industrial clusters" represents a high opportunity to integrate more rapidly new suppliers and obtain multiplying effects. A cluster is defined as a concentration of 'interdependent' firms 
within the same or adjacent industrial sectors in a small geographical area (Observatory of European SME's, 2002). Porter (1990) defines a cluster as a set of industries related through buyer-supplier and supplier-buyer relationships, or by common technologies, common buyers or distribution channels, or common labour pools. Therefore, Swiss firms can gain benefits by collaborating with suppliers in specialised industrial clusters, as for instance, consolidating raw materials from different suppliers in the cluster to reduce logistics and benefiting from their proximity to implement Just-in-Time practices reducing logistics costs and lead times. It is also important to highlight that UNIDO has a joint programme with the Indian government to support SME's in special locations to technologically catch-up and improve their manufacturing capabilities to better integrate with global value chains. One very successful case study was identified in Bangalore, where a very well developed cluster of the Machine Tool Making Industry was found. During the SWISSMAIN Indian pilot, the CEO of Ace Micromatic, one of the main Indian OEMs in this sector, was interviewed as he is leading this cluster in Bangalore. The cluster counts with more than 30 Indian partners (both SME's and OEMs) who are sharing best practices to increase their competitiveness. Recently this cluster has started to increase its exports to Asia being considered a very successful cluster project by UNIDO. Additionally, the Indian government has a new programme to develop the following new clusters: Pune, Vododara and Ludhiana (table 3).

Finally, for the innovation considering the complete product life cycle, again the "new services" services scenario seems a very feasible approach to add value in the complete product life cycle, specially when the Swiss production facility is in Switzerland and it is costly for the company to setup a new office in India only for these services. In fact, the "new services" scenario is currently applied by several companies in the machine tool sector in India with Japanese counterparts to provide maintenance services to products, local training to customers and product re-design according to local specific needs.

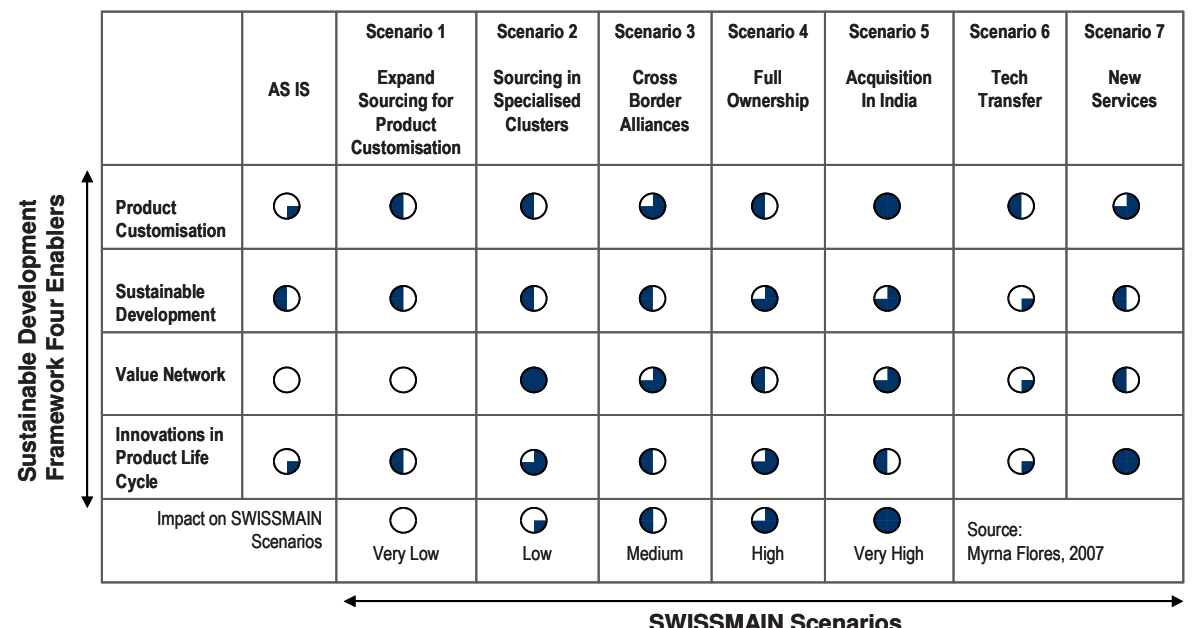

Table 2. Sustainable Innovation Framework applied to SWISSMAIN to Benchmark the seven identified scenarios 
As the next step of this scenario benchmarking approach, a roadmap can be suggested to start step by step new Indo-Swiss collaborations. In the case of the SWISSMAIN Indian Pilot, two key scenarios are currently being targeted by the industrial project partners for next steps:

Scenario 2: To develop a clear understanding of the Indian clusters' technological and production skills, competences, directory of suppliers and range of prices. Table 3 and Figure 3 show the three main identified clusters which could provide machined components in India to Swiss entrepreneurs.

\begin{tabular}{|c|c|c|c|c|c|}
\hline & Quality & $\begin{array}{c}\text { Low } \\
\text { Volumes }\end{array}$ & Price & Guidelines & Specialisation of each cluster \\
\hline Pune & 1 & 3 & 3 & 1 & $\begin{array}{l}\text { Precision engineering, } \\
\text { automotive, machine tools }\end{array}$ \\
\hline Vadodara & 2 & 1 & 2 & 2 & $\begin{array}{l}\text { Castings, fabrications, heat } \\
\text { treatment, precision machining }\end{array}$ \\
\hline \multirow[t]{2}{*}{ Ludhiana } & 3 & 2 & 1 & 3 & $\begin{array}{l}\text { Castings, forging, not high } \\
\text { precision }\end{array}$ \\
\hline & \multicolumn{2}{|c|}{1 best option } & \multicolumn{2}{|c|}{3 worse option } & Source: Myrna Flores, 2007 \\
\hline
\end{tabular}

Table 3. Identified Clusters in India for machined components (Source EDI India, 2007)

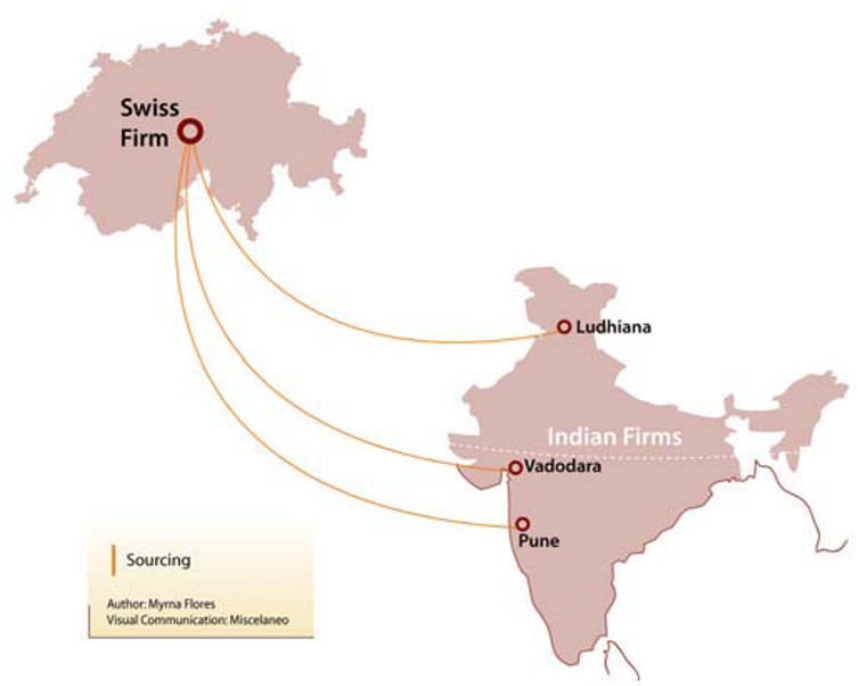

Figure 3. Concentrate Sourcing in Developed/Developing Industrial Clusters (Scenario 2)

Scenario 7: To identify which services could be developed to cover all the value chain. Specific needs from interviewed Swiss companies in India also include vocational training services for technical personnel to operate advanced machinery and maintenance service to customers. Local Universities can also be seen as 
partners to support the training services and the collaborative product design. Figure 4 presents the Scenario 7 of SWISSMAIN.

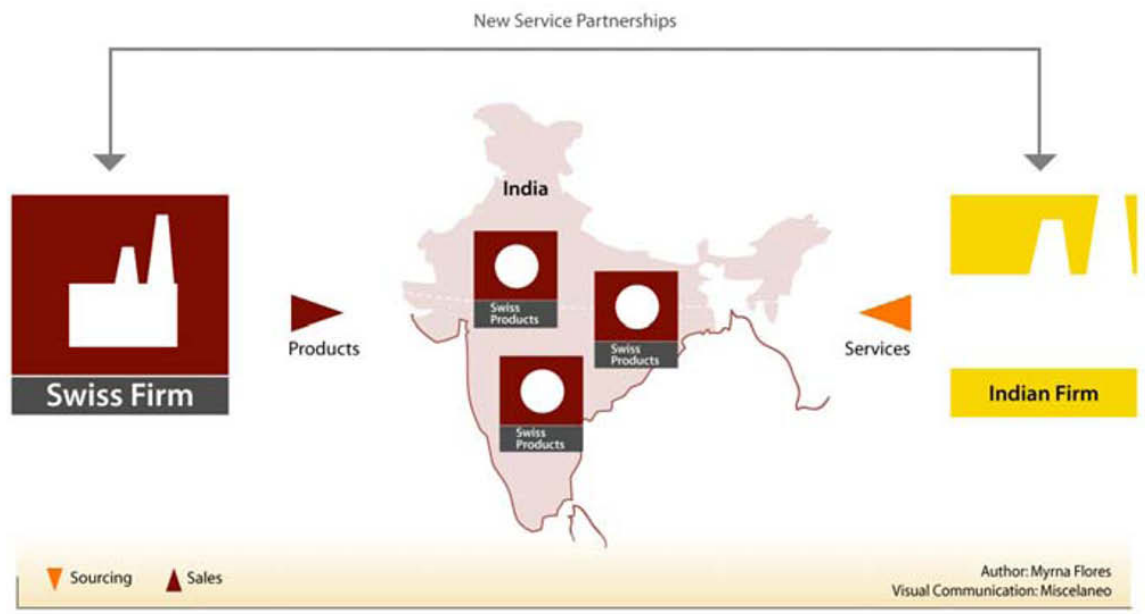

Figure 4. New Services Partnerships (scenario 7)

\section{CONCLUSIONS}

The current paper proposed a new sustainable innovation framework integrating key concepts such as innovation, collaboration and sustainable development. This framework was used as a guideline and benchmarking tool to compare the seven identified scenarios. It is also important to mention that by applying this framework during the SWISSMAIN Indian pilot, several weaknesses and strengths of each scenario were identified specially for the deployment of sustainable development practices and collaboration to obtain as target result high innovation outputs. Future efforts should concentrate to further develop the framework to develop a methodology consisting of quantitative measures to have proper Key Performance Indicators (KPI's) that can quantify not only qualitatively but quantitatively each enabler to support the comparison and right selection of the best potential TO BE collaboration scenario by Swiss SME's.

\section{ACKNOWLEDGEMENTS}

The authors would like to thank the Swiss Innovation Promotion Agency - CTI International for the funding provided to realise the SWISSMAIN Indian Pilot. Gratitude is also given to Mr. Duruz from Maillefer and Mr. Voirol from BoschSapal, industrial partners of the SWISSMAIN project, who provided their business requirements to develop the scenarios. We also sincerely thank Prof. L.S. Ganesh, Prof. Srinivasan and Prof. Prakash Sai, from the Indian Institute of Technology in Madras for supporting this Indo-Swiss research project and the 15 Swiss and Indian 
firms and organisations, which participated actively in the project during the face to face interviews.

A special thank you note is also given to the University of Applied Sciences of Southern Switzerland (SUPSI), for supporting Myrna Flores to lead the SWISSMAIN Indian Pilot while working at the Institute CIM for Sustainable Innovation (ICIMSI) and to Michel Pouly from the Swiss Federal Institute of Technology, Lausanne (EPFL), the project leader of the SWISSMAIN project, who invited Myrna Flores as a visiting researcher in EPFL to develop this research. Last but not least we thank Ana Beatriz Dominguez Organero for her great work in the graphic design of visual information.

\section{REFERENCES}

Brent C., and Labuschagne C., 2007, An appraisal of social aspects in project and technology life cycle management in the process industry, Management of Environmental Quality, An International Journal, 18: 413-426

Camarinha-Matos L. and Afsarmanesh H., Collaborative Networked Organizations, A research agenda for emerging business models, 2004

Charter M. and Clark T., 2007, Sustainable Innovation Key conclusions from Sustainable Innovation Conferences 2003-2006, The Centre for Sustainable Design University College for the Creative Arts, www.cfsd.org.uk

Chesbrough H., Open Business Models, How to Thrive in the New Innovation Landscape, Harvard Business School Press, 2006

Entrepreneurship Development Institute of India (EDI-India), http://www.ediindia.org

Da Silveira G., Borenstein D., Fogliatto F., 2001, Mass customization: Literature review and research directions, Int. J. Production Economics 72:1-13

Flores M., Boer C., Canetta L., Pouly M., Cherian M., 2008, "Critical Success Factors and Challenges to develop new Sustainable Supply Chains in India based on Swiss Experiences", To be published in the International Conference of Concurrent Enterprising, ICE Conference Proceedings 2008

Friedman T., 2005, The World is Flat, Ed. Penguin

Huang G., Simpson T., Pine, B.J. II., 2005, The power of product platforms in mass customisation, Int. Journal of Mass Customisation, Inderscience Enterprises Ltd, 1: 1-13

Kocabasoglu C., Prahinski C. Klassen R., 2007, Linking forward and reverse supply chain investments: The role of business uncertainty, Journal of Operations Management, 25: $1141-1160$

Living Labs Project, http://www.livinglabs-europe.com/livinglabs.asp

Mont O. and Bleischwitz R., 2007, Sustainable Consumption and Resource Management in the Light of Life Cycle Thinking, European Environment 17: 59-76

Observatory of European SMEs, Regional clusters in Europe, European Community, http://europa.eu.int/comm/enterprise, (2002)

Porter M., The Competitive Advantage of Nations. Free Press, New York, 1990.

Rocha M., Searcy C. and Karapetrovic S., 2007, Integrating Sustainable Development into Existing Management Systems, Total Quality Management, 18:,83 - 92

Schoemaker, P., 1995, Scenario Planning: A Tool for Strategic Thinking, Sloan Management Review; Winter 1995; 36, 2

United Nations, General Assembly, Brundtland Report: Our Common Future: Report of the World Commission on Environment and Development, available at: http://www.worldinbalance.net/pdf/1987-brundtland.pdf 
United Nations Industrial Development Organization (UNIDO) Cluster Development Programme in India, http://www.smallindustryindia.com/clusters/unido/cdp.htm

Wetherill M., Rezgui Y., Boddy S. and Cooper G, 2007, Intra- and Inter-organizational Knowledge Services to Promote Informed Sustainability Practices, Journal of Computing in Civil Engineering, 21: 78-89 